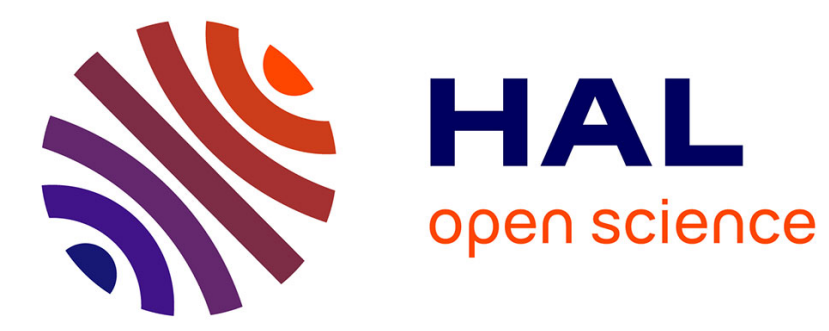

\title{
Number of honeybee colonies in areas with high and low beekeeping activity in Southern Mexico
}

Robin Moritz, F. Kraus, Anett Huth-Schwarz, Stephan Wolf, Claudia Carrillo, Robert Paxton, Rémy Vandame

\section{- To cite this version:}

Robin Moritz, F. Kraus, Anett Huth-Schwarz, Stephan Wolf, Claudia Carrillo, et al.. Number of honeybee colonies in areas with high and low beekeeping activity in Southern Mexico. Apidologie, 2012, 44 (1), pp.113-120. 10.1007/s13592-012-0163-8 . hal-01201279

HAL Id: hal-01201279

https://hal.science/hal-01201279

Submitted on 17 Sep 2015

HAL is a multi-disciplinary open access archive for the deposit and dissemination of scientific research documents, whether they are published or not. The documents may come from teaching and research institutions in France or abroad, or from public or private research centers.
L'archive ouverte pluridisciplinaire HAL, est destinée au dépôt et à la diffusion de documents scientifiques de niveau recherche, publiés ou non, émanant des établissements d'enseignement et de recherche français ou étrangers, des laboratoires publics ou privés. 


\title{
Number of honeybee colonies in areas with high and low beekeeping activity in Southern Mexico
}

\author{
Robin F. A. Moritz ${ }^{1,2}$, F. Bernhard Kraus ${ }^{1}$, Anett Huth-Schwarz ${ }^{1}$, \\ Stephan $\mathrm{Wolf}^{1,3}$, Claudia A. Castillo CArrillo ${ }^{4}$, Robert J. PaXton ${ }^{1}$, \\ Rémy VANDAME ${ }^{5}$ \\ ${ }^{1}$ Institut für Biologie, Martin-Luther-Universität Halle-Wittenberg, 06099 Halle/Saale, Germany \\ ${ }^{2}$ Department of Zoology and Entomology, University of Pretoria, 0002 Pretoria, South Africa \\ ${ }^{3}$ Rothamsted Research, West Common, Harpenden, Hertfordshire AL5 2JQ, UK \\ ${ }^{4}$ Facultad de Medicina Veterinaria y Zootecnia, Universidad Autónoma de Yucatán, Apdo. postal 4-11697100 \\ Mérida, Yucatán, Mexico \\ ${ }^{5}$ ECOSUR, Carretera Panamericana y Periférico Sur, San Cristóbal de Las Casas, Chiapas, Mexico
}

Received 16 April 2012 - Revised 27 June 2012 - Accepted 19 July 2012

\begin{abstract}
The number of colonies in feral and managed honeybee populations (Apis mellifera) was determined for various sampling locations in Chiapas and Yucatan (Mexico) to assess the impact of apiculture on feral honeybee populations. We used a comparative sampling approach determining the number of colonies in similar habitats and landscapes but with different intensity of beekeeping. Sampling sites included nature reserves, and mango and shaded coffee plantations. The agricultural sites were all set in high-diversity landscapes with plenty of surrounding secondary forest. The number of colonies was determined by genotyping drones caught on drone congregation areas and assigning the drone genotypes to mother queens each heading a colony. We used three sets of linked markers each to achieve sufficient resolution for a precise colony assignment. The estimated colony numbers ranged from 34 to 54 colonies, with an average of $38.3 \pm 6.9$ colonies in areas with high and $43.5 \pm 6.6$ colonies in areas with low beekeeping activity. There was no significant difference in colony numbers between the sites with high and low beekeeping activity suggesting that the managed honeybee populations do not substantially add to the overall number of honeybee colonies supported in the wild. This might indicate that restrictions on apicultural activities to prevent any potential conservation conflict with native pollinators might not be useful, since honeybee colonies are very abundant in many different landscapes in Southern Mexico independent of apiculture.
\end{abstract}

\section{Apis mellifera / beekeeping / honeybee / microsatellites / pollinator decline / population size}

\section{INTRODUCTION}

The western honeybee Apis mellifera is not native to the American continent and was imported with the early European settlers to establish apiculture on a continent which had no honeybees. Since then, the initially managed

Corresponding author: F.B. Kraus,

kraus@zoologie.uni-halle.de

Manuscript editor: David Tarpy honeybee population escaped into the wild where it established feral honeybee populations. These were for many centuries of European origin until the feral population in South and Central America experienced a complete genetic exchange after the arrival of Africanized honeybees in 1986 (Moffett et al. 1987; Rowell et al. 1992). African honeybees had been introduced into Brazil in 1956 with the aim of improving honey production among managed colonies in the American tropics (Kerr 1967). These honeybees of tropical African origin expanded rapidly and admixed with the European honeybees, forming hybrid populations which are 
characterized by an asymmetric proportion and dominance of genes and behaviours of African origin (Schneider et al. 2004; Kraus et al. 2007; Guzmán-Novoa et al. 2011). At the same time, apiculture has been suspected to contribute to native bee declines (Roubik 1978; Roubik and Wolda 2001). In Mexico, a country globally ranking sixth in honey production with 52,900 tons in 2010 (SAGARPA 2011), there is obviously a large managed honeybee population. In addition, however, there is also a high density of feral colonies, which became particularly high after the invasion of the Africanized honeybees (Ratnieks et al. 1991; Schneider et al. 2004). There has been repeated concern that the high number of managed honeybee colonies cause local pollen and nectar depletion resulting in reduced resource availability for native endemic pollinators (Cairns et al. 2005). At the same time, breeding programmes to improve the Africanized honeybee for beekeeping have been implemented (Guzmán-Novoa and Page 1999; Zárate et al. 2008) which may further enhance the colony densities of $A$. mellifera. Hence, the number of colonies may be a paramount parameter for assessing the impact of apiculture on the conservation of pollinator biodiversity. In the extreme, it might be necessary to impose restrictions on apicultural practice as a measure for maintaining biodiversity of other endemic pollinators as has been recommended for Australia (Gross and Mackay 1998) and where honeybees are considered to be a pest species by some conservationists (Lindenmayer et al. 2009). Here, we study if regions with intensive apiculture had higher numbers of colonies than regions with no beekeeping activity to see if such regulations could reduce any potential competition between $A$. mellifera and other bees.

\section{MATERIALS AND METHODS}

We sampled drones in ten different regions of Chiapas (Figure 1; GPS data in Table I) and two regions of the Yucatan peninsula (GPS data only, Table I) in Southern Mexico, either with high beekeeping activity or regions lacking apicultural activity according to the local knowledge of El Colegio de la Frontera Sur (ECOSUR) specialists and beekeepers. The time frame over which the apicultural activity was considered was approximately 20 years. Sampling sites included nature reserves and mango and shaded coffee plantations. We used a comparative sampling approach, sampling in ecologically similar habitats under either the high or low beekeeping regime. Since feral colonies are extremely cryptic and hard to detect, we used a sampling technique based on drone trapping on drone congregation areas (DCAs) that allows for representative, unbiased population samples for both feral and managed populations (Moritz et al. 2007). This sampling approach in combination with linked markers (see below) is very precise and superior to a sample of workers and/or the usage of unlinked markers. The sampling of workers would harbour the problem that worker samples are usually highly biassed due to the mass recruiting to a given food source, which renders an estimate of colony numbers difficult. The drones sampled for our study were caught at DCAs using black-painted cigarette filters impregnated with synthetic queen mandibular pheromone (9-ODA) and an insect net, attached to a helium-filled weather balloon (Williams 1987). After capture, the drones were transferred into $75 \%$ ethanol and stored at $-20{ }^{\circ} \mathrm{C}$ until DNA extraction.

\subsection{DNA analyses}

DNA was extracted from the hind legs of more than 90 of the sampled drones per sample location $(1,296$ drones in total) with Chelex standard extraction procedures (Walsh et al. 1991) and genotyped with a set of 12 loci on three linkage groups (Table II; Shaibi et al. 2008). Four linked markers each were chosen on chromosome 3 next to the sex locus (csd) (Beye et al. 2003) which determines sex (markers span $11.6 \mathrm{~kb}$ or $0.2 \mathrm{~cm}$ ). The second linkage group was on chromosome 13 next to the thelytoky gene (Lattorff et al. 2007), which controls worker reproduction (markers span $11.2 \mathrm{~kb}$ or $0.19 \mathrm{~cm}$ ). The third linkage group is on chromosome 16 in a large 'gene desert' expected to be selectively neutral. With this set of markers, the precision of the analyses is more than an order of magnitude larger than is standard genotyping with unlinked loci (Shaibi et al. 2008). We used an 


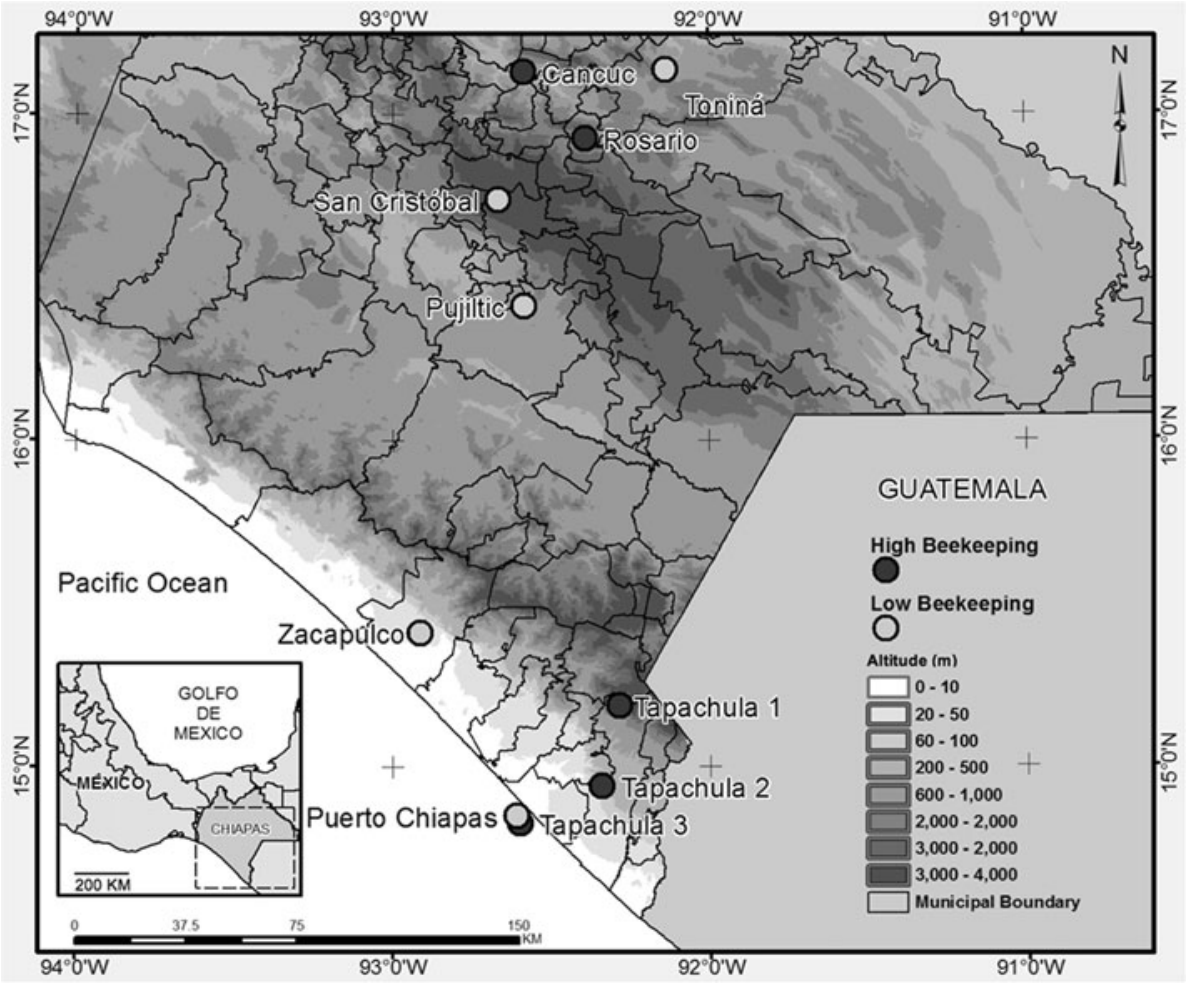

Figure 1. Satellite image map of sample locations in Chiapas. For exact GPS coordinates, see Table I.

Table I. Geographic data (GPS) and sample sizes for the 12 sampling locations in Chiapas and Yucatan (Mexico).

High beekeeping

Tapachula 1 (mango plantation)

Tapachula 2 (ECOSUR, garden, urban landscape)

Tapachula 3 (mango plantation)

Rosario (agriculture: maize, grassland)

Cancuc (extensive agriculture, river valley)

Izamal (deciduous forest, thorny bushes and shrubs)

Low beekeeping

Zacapulco (mangrove)

Puerto Chiapas (mangrove, grassland)

Toniná (patchy, agriculture and secondary forest)

San Cristóbal (agriculture, pine forest)

Pujiltic (sugarcane plantation)

Dzoncauich (low deciduous forest)
$\mathrm{N} 14^{\circ} 55.968^{\prime}-\mathrm{W} 92^{\circ} 17.013^{\prime}$

135

$\mathrm{N} 14^{\circ} 53.199^{\prime}-\mathrm{W} 92^{\circ} 17.215^{\prime}$

114

$\mathrm{N} 14^{\circ} 49.025^{\prime}-\mathrm{W} 92^{\circ} 20.954^{\prime}$

183

$\mathrm{N} 16^{\circ} 53.154^{\prime}-\mathrm{W} 92^{\circ} 16.452^{\prime}$

96

$\mathrm{N} 16^{\circ} 55.770^{\prime}-\mathrm{W} 92^{\circ} 25.614^{\prime}$

$\mathrm{N} 20^{\circ} 57.328^{\prime}-\mathrm{W} 88^{\circ} 59.865^{\prime}$

$\mathrm{N} 15^{\circ} 11.817^{\prime}-\mathrm{W} 92^{\circ} 53.112^{\prime}$

$\mathrm{N} 14^{\circ} 46.290^{\prime}-\mathrm{W} 92^{\circ} 28.518^{\prime}$

$\mathrm{N} 16^{\circ} 53.910^{\prime}-\mathrm{W} 92^{\circ} 0.486^{\prime}$

$\mathrm{N} 16^{\circ} 44.016^{\prime}-\mathrm{W} 92^{\circ} 36.240^{\prime}$

$\mathrm{N} 16^{\circ} 17.460^{\prime}-\mathrm{W} 92^{\circ} 26.544^{\prime}$

$\mathrm{N} 21^{\circ} 08.324^{\prime}-\mathrm{W} 88^{\circ} 52.854^{\prime}$ 
Table II. Characteristics of the used microsatellite DNA markers.

\begin{tabular}{lcll}
\hline Locus & Chromosome & \multicolumn{2}{c}{ Primer sequences $\left(5-3^{\prime}\right)$} \\
\cline { 3 - 4 } & & \multicolumn{1}{c}{ Forward } & \multicolumn{1}{c}{ Reverse } \\
\hline HB-SEX-01 & 3 & HEX-AGTGCAAAATCCAAATCATC & ATTCGATCACCCAAAGAA \\
UN351 & 3 & FAM-AGCATACTTCTTCACCGAACCAC & TCCGTTTATGCTTCATTTTCGA \\
HB-SEX-02 & 3 & HEX-ACGCATTGAAGGATATTATGA & AATTTGAACATTCGATCACC \\
HB-SEX-03 & 3 & TET-AACGTGGAAGATAACTTTAACAA & ACAATGTTATGATTTTTCACGA \\
HB-THE-01 & 13 & FAM-GACGATTTACGAGGTTTCAC & TCGATTTCGTTTCGTTTTAT \\
HB-THE-02 & 13 & TET-GGGAAAGATATTAGGGAGGA & CGACGAAAAATTACAAGGAC \\
HB-THE-03 & 13 & FAM-TAACTGGTCGTCGGTGTT & CACGTAGAGAATCCCATTGT \\
HB-THE-04 & 13 & HEX-GCTGGAAGGGAACTGTAGA & GGACGCGTTTTAATATCTCA \\
HB-C16-01 & 16 & HEX-AAAATGCGATTCTAATCTGG & TTGCCTAAAATGCTTGCTAT \\
AC006 & 16 & TET-GATCGTGGAAACCGCGAC & CACGGCCTCGTAACGGTC \\
HB-C16-02 & 16 & TET-TAGTATCGTGCTGTTCATCG & ACATACATCTCTTGGCGAGT \\
HB-C16-05 & 16 & FAM-ATTTTATGCGCGTTTCGTA & CATGGCTCCTCCATTAAATC \\
\hline
\end{tabular}

DNA was Chelex-extracted (Walsh et al. 1991) from one leg of each bee. Multiplex PCR solutions contained $10 \mu \mathrm{L}$ of $10-$ $100 \mathrm{ng}$ DNA, $1 \times$ PCR Master Mix (Promega) and $0.2 \mu \mathrm{m}$ of each primer ( $5^{\prime}$ label). PCR programme: denaturation for 5 min at $95{ }^{\circ} \mathrm{C}, 35$ cycles of $30 \mathrm{~s}$ at $95{ }^{\circ} \mathrm{C}, 30 \mathrm{~s}$ of annealing at $55^{\circ} \mathrm{C}$, extension for $1 \mathrm{~min}$ at $72{ }^{\circ} \mathrm{C}$, final elongation for $20 \mathrm{~min}$ at $72{ }^{\circ} \mathrm{C}$ in a GeneAmp 9,700 thermocycler (PerkinElmer/Applied Biosystems). Genotyping was done in a MegaBace automatic sequencer. HEX, Fam and Tet are the fluorescence labels

ANOVA to test for the effect of the linkage group and beekeeping intensity on the haplotype diversity.

\subsection{Colony assignment and estimated number of colonies}

The genotypes of the drone-producing queens were inferred using the COLONY software (Wang 2004) by treating each haplotype per chromosome as an independent allele of the same locus. We determined the probability that two identical genotypes could have been detected in two different individuals by chance (the non-detection error). We estimated the nondetection error following Boomsma and Ratnieks (1996). In addition, queens may remain undetected because of a small sample size (non-sampling errors). This type of error was determined by fitting the empirical drone frequencies of the assigned mother queens to a Poisson distribution (Jaffé et al. 2009). The final sample size-corrected number of queens was obtained by adding those queens with an expected drone frequency of zero to the detected number of queens resulting in the estimated number of colonies.
We used a $t$ test to test for differences in colony numbers between the regions with high and low beekeeping activity.

\section{RESULTS}

\subsection{Genetic diversity}

Rather than determining the classical parameters of population genetics based on the variability of individual loci such as allelic richness or expected heterozygosity, it seemed more meaningful to determine the number of haplotypes to compare the different populations and variability in the linkage groups. The number of haplotypes per linkage group varied largely, with 38 to 64 haplotypes for chromosome 3 (sex chromosome), 20 to 56 haplotypes for chromosome 13 and 17 to 49 haplotypes for chromosome 16 (Figure 2). As a result, the overall non-detection error was extremely low (error rate, $<0.0001$ ). There were significant differences among the three different linkage groups (ANOVA, d.f. $=2, F=10.02$, 


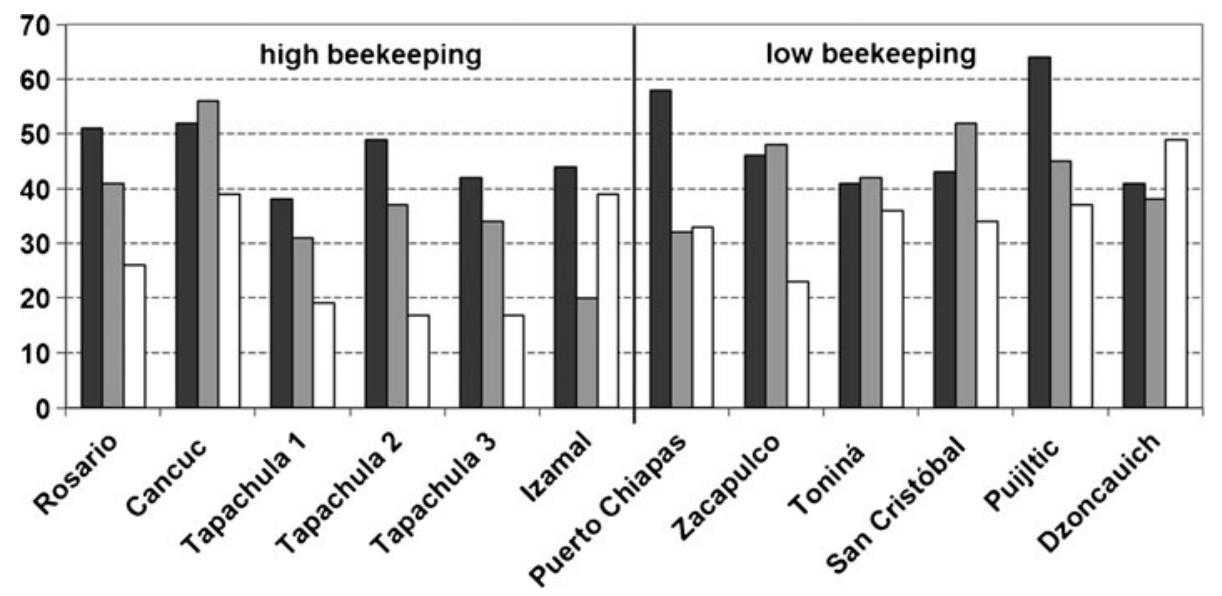

Figure 2. The number of haplotypes per linkage group in the various sampled populations with (left) and without beekeeping (right). Black=chromosome 3 (sex locus), grey=chromosome 13, white=chromosome 16.

$P<0.001)$, with the markers on chromosome 3 (sex chromosome) being most variable (47.4 \pm 7.7 haplotypes), those of chromosome 13 showing intermediate variability (39.7 \pm 9.9 haplotypes) and those on chromosome 16 showing least variability ( $30.8 \pm 10.2$ haplotypes). The difference in haplotype numbers between the regions with and without beekeeping was not significant (ANOVA, d.f. $=1, F=4.03, P>0.05$ ), and the overall mean was $39.3 \pm 11.4$ haplotypes.

\subsection{Number of colonies}

The estimated colony numbers based on the drone genotypes ranged from 34 colonies in Tapachula up to 54 colonies in Puijltic, which are both located in Chiapas (Figure 1). Overall, we obtained similar results for the estimated number of colonies for the DCAs with high ( $38.3 \pm 6.9$ colonies) and with low (43.5 \pm 6.6 colonies) beekeeping activity (Figure 3). Thus, the number of estimated colonies yielded no significant differences between these two groups ( $t$ test, $t=-1.4$, d.f. $=10, P=0.19$ ), in spite of a large total sample set of over 11,000 genotypes from over 1,296 individuals.

\subsection{Number of drones per colony}

We confined ourselves to the more reliable genotypic analyses for colony assignment based on the linked genotypes only and could infer a total of 491 potential mother colonies based on the 1,296 drone genotypes. Most of the colonies (48\%) contributed only two drones to the sample, and we are even left with 29 undetected colonies, if our drones reflected a random sample of evenly contributing colonies (Figure 4). The large number of detected colonies reduces the number of reliable mother queen genotypes that are confirmed by multiple drone genotypes. To allow for a reliable estimate of individual mother queens based on at least six drones per colony, this would have required a threefold greater sample size after genotyping (Lepais et al. 2010), probably exceeding the resources allocated today for microsatellite-based studies in molecular ecology.

\section{DISCUSSION}

This study adds to the notion that honeybee colony numbers in the tropics can reach extremely high values. The number of colonies contributing drones to a given drone congregation area in Southern Mexico is similar to those found in wild populations in tropical Africa (Jaffé et al. 2010). Surprisingly, beekeeping had no significant effect on the number of detected honeybee colonies at all. In fact, the estimated number of colonies was higher in the regions 


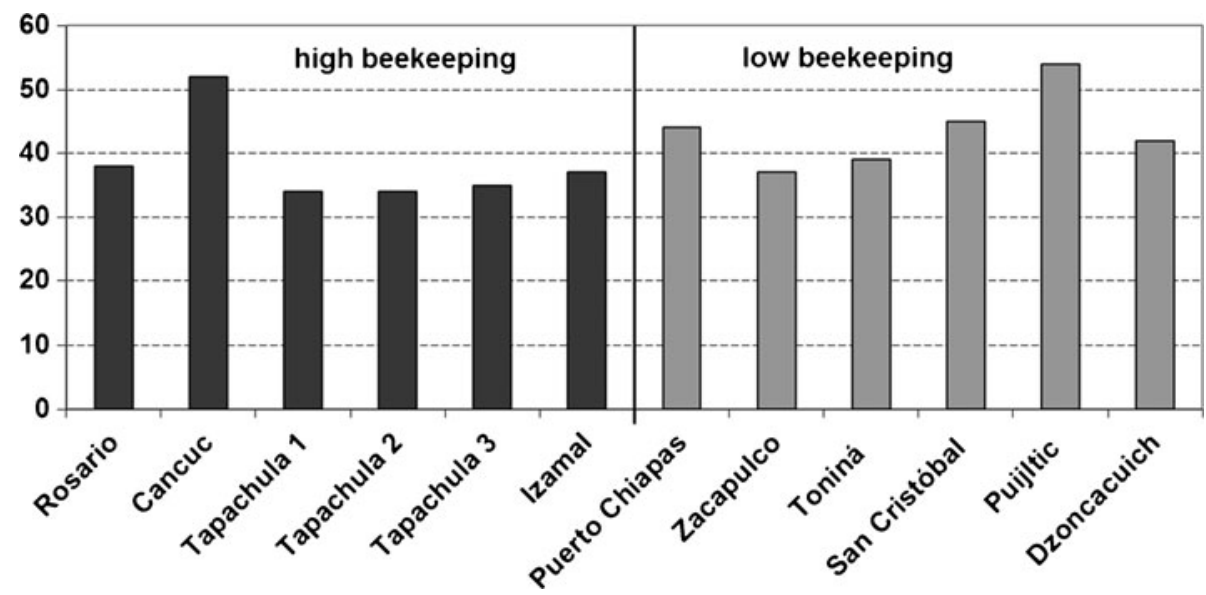

Figure 3. The estimated number of colonies at the various sampling locations (black=high beekeeping, grey= low beekeeping).

without beekeeping than with beekeeping, albeit not significant. This suggests that the majority of colonies in the honeybee populations in Chiapas and Yucatan lives in the wild as feral honeybee colonies, and managed colonies only marginally contribute to the overall population. The situation is thus very similar to tropical
Africa where apicultural colonies only marginally contribute to the overall population in habitats with sufficiently undisturbed landscapes (Jaffé et al. 2010).

Since our results indicate that the majority of the honeybees resides in the wild, restrictions on apicultural activities to prevent any potential

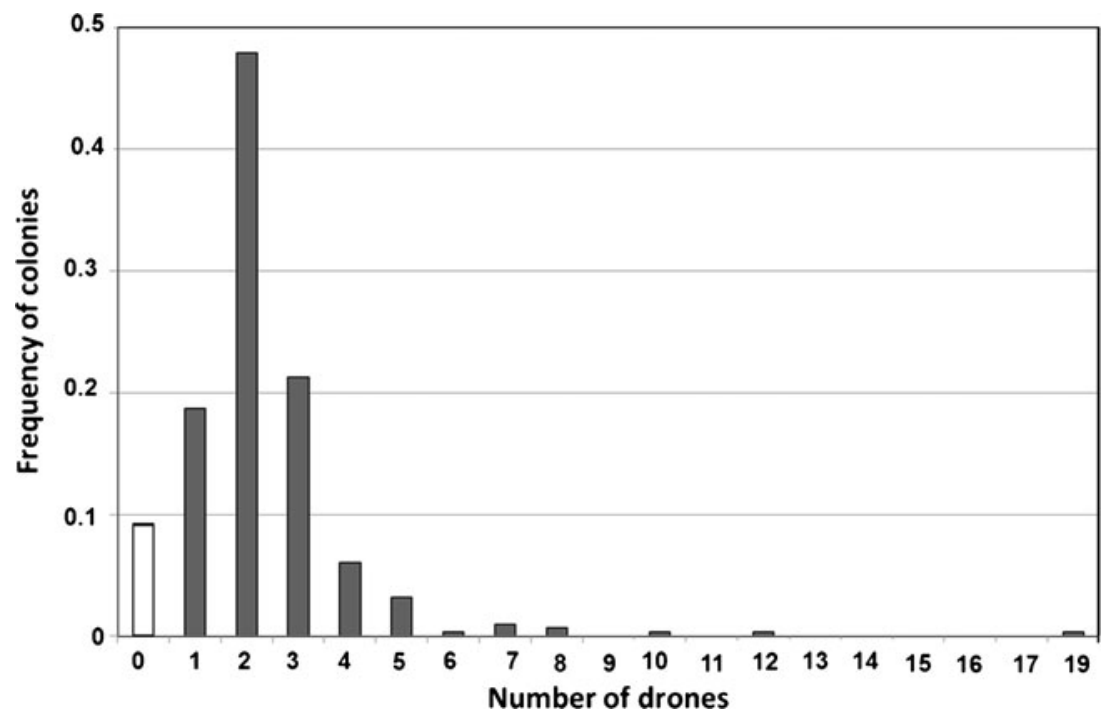

Figure 4. The number of drones sampled per colony based on a total of 491 detected colonies. In spite of a high average sample size of drones per sample location, the reliability of inferred queen genotypes is low, and the predicted number of undetected colonies, which provided nil drones to the sample, remained high (white bar) due to the high number of colonies contributing drones to a given drone congregation area. 
conservation conflict appear not to be useful. In general, however, it seems the conflict scenario between honeybee and other pollinator species has only weak support from empirical evidence in Central America (Moritz et al. 2005). There are no reports about extinctions due to feral honeybees, neither in North nor in Central or South America although the spread of the Africanized honeybee has been meticulously and extremely carefully scrutinized over decades (Roubik et al. 1986).

From a population genetic perspective, it is interesting to see that the variability of markers near the sex locus was significantly higher than that of the other two linkage groups. Since there is a strong negative frequency-dependent selection operating on the sex alleles due to its genetic load in the female sex (Zayed 2004, 2009), this may reflect natural selection for heterozygosity in the females. Homozygote diploid individuals do not develop into females but instead into diploid males (Mackensen 1951) that are cannibalized by the workers immediately after hatching from the egg and hence functionally lethal (Woyke 1963). In a recent study on a closed population on the Dutch island of Schiermonnikoog, Lattorff et al. (2012, in review) inferred that the haplotype variability of the markers used in this study is indeed closely correlated with functional allelic variability at the sex locus. For every haplotype they detected, they found 4.3 functional alleles. If this ratio also holds for the Mexican honeybee populations, this would range from 9 to 15 functional sex alleles in the sampled populations. This compares well with previous estimates that range between 11 and 19 sex alleles in various honeybee populations (Mackensen 1955; Laidlaw et al. 1956; Adams et al. 1977).

In conclusion, we see a very vital feral honeybee population that seems to prosper independent of the landscapes tested. Even in regions with intensive apiculture, the number of colonies remains the same which may be due to the rich environmental resources and a highly diverse agricultural landscape with a lack of kolkhoz-type large-scale agricultural landscape destructions.

\section{ACKNOWLEDGMENTS}

This work was funded by the Mexican-European FONCICYT 94293 grant 'MUTUAL-Mutualisms with bees in tropical landscapes: risks and rescue for biodiversity and crop production'. We would like to thank the two anonymous referees for helpful comments on an earlier version of this manuscript.

Nombre de colonies d'abeilles dans des zones où l'apiculture représente une activité importante ou non, dans le sud du Mexique

Apis mellifera / apiculture / microsatellites / déclin des pollinisateurs / taille de la population

Anzahl von Bienenvölkern in Gebieten mit hoher und geringer Dichte von Bienenhaltung im Süden von Mexiko

Apis mellifera / Bienenhaltung / Honigbiene / Mikrosatelliten / Bestäuberrückgang / Populationsgröße

\section{REFERENCES}

Adams, J., Rothman, E.D., Kerr, W.E., Paulino, Z.L. (1977) Estimation of the number of sex alleles and queen matings from diploid male frequencies in a population of Apis mellifera. Genetics 86, 583-596

Beye, M., Hasselmann, M., Fondrk, M.K., Page, R.E., Omholt, S.W. (2003) The gene csd is the primary signal for sexual development in the honeybee and encodes an SR-type protein. Cell 114, 419-429

Boomsma, J.J., Ratnieks, F.L.W. (1996) Paternity in eusocial Hymenoptera. Phil. Trans. R. Soc. B 351, 947-975

Cairns, C.E., Villanueva-Gutierrez, R., Koptur, S., Bray, D.B. (2005) Bee populations, forest disturbance, and Africanization in Mexico. Biotropica 37, 686-692

SAGARPA (La Secretaría de Agricultura, Ganadería, Desarrollo Rural, Pesca y Alimentación de México) (2011) Incrementa 8.9 por ciento la producción de miel en México. Press release num. 642/11

Gross, C.L., Mackay, D. (1998) Honeybees reduce fitness in the pioneer shrub Melastoma affine (Melastomataceae). Biol. Conserv. 86, 169-178

Guzmán-Novoa, E., Page, R.E. (1999) Selective breeding of honey bees (Hymenoptera: Apidae) in Africanized areas. J. Econ. Entomol. 92, 521-525

Guzmán-Novoa, E., Espinosa Montaño, L.G., Correa Benítez, A., Guzmán Novoa, G. (2011) Colonización, impacto y control de las abejas melíferas africanizadas en México. Vet. Mex. 42, 149-178 
Jaffé, R., Dietemann, V., Crewe, R.M., Moritz, R.F.A. (2009) Temporal variation in the genetic structure of a drone congregation area: an insight into the population dynamics of wild African honeybees (Apis mellifera scutellata). Mol. Ecol. 18, 15111522

Jaffé, R., Dietemann, V., Allsopp, M.H., Costa, C., Crewe, R.M., Dall'Olio, R., De la Rúa, P., ElNiwieri, M.A.A., Fries, I., Kezic, N., Meusel, M.S., Paxron, R.J., Shaibi, T., Stolle, E., Moritz, R.F.A. (2010) Estimating the density of honeybee colonies across their natural range to fill the gap in pollinator decline censuses. Conserv. Biol. 24, 583-593

Kerr, W.E. (1967) The history of the introduction of Africanized bees in Brasil. S. Afr. Bee J. 39, 3-5

Kraus, F.B., Frank, P., Vandame, R. (2007) Asymmetric introgression of African gens in honeybee populations (Apis mellifera L.) in Central Mexico. Heredity 99, 233-240

Laidlaw, H.H., Gomes, F.P., Kerr, W.E. (1956) Estimations of the number of lethal alleles in a panmictic population of Apis mellifera. Genetics 41, 179-188

Lattorff, H.M.G., Moritz, R.F.A., Crewe, R.M., Solignac, M. (2007) Control of reproductive dominance by the thelytoky gene in honeybees. Biol. Lett.. doi: dx.doi.org3:292-295

Lattorff, H.M.G., Medrano, M., Duchateau, M.J., Moritz, R.F.A. (2012) Microsatellite DNA markers, as a tool for identifying functional sex alleles the honeybee (Apis mellifera). Mol. Ecol. (in press)

Lepais, O., Darvill, B., O'Connor, S., Osborne, J.L., Sanderson, R.A., Cussans, J., Goffe, L., Goulson, D. (2010) Estimation of bumblebee queen dispersal distances using sibship reconstruction method. Mol. Ecol. 19, 819-831

Lindenmayer, D.B., Welsh, A., Donnelly, C., Crane, M., Michael, D., Macgregor, C., McBurney, L., Montague-Drake, R., Gibbons, P. (2009) Are nest boxes a viable alternative source of cavities for hollow-dependent animals? Long-term monitoring of nest box occupancy, pest use and attrition. Biol. Conserv. 142, 33-42

Mackensen, O. (1951) Viability and sex determination in the honeybee (Apis mellifera). Genetics 36, 500-509

Mackensen, O. (1955) Further studies on a lethal series in the honeybee. J. Hered. 46, 72-74

Moffett, J.O., Dale, L.M., Thomas, A., Fierro, M.M. (1987) The Africanized bee in Chiapas, Mexico. Am. Bee J. 127, 517-519

Moritz, R.F.A., Härtel, S., Neumann, P. (2005) Global invasions of the western honey bee (Apis mellifera) and the consequences for biodiversity. Ecoscience 12, 289-301
Moritz, R.F.A., Kraus, F.B., Kryger, P., Crewe, R. (2007) The size of wild honeybee populations (Apis mellifera) and its implications for the conservation of honeybees. J. Insect. Conserv. 11, 391-397

Ratnieks, F.L.W., Piery, M.A., Cuadriello, I. (1991) The natural nest and nest density of the Africanized honey-bee (Hymenoptera, Apidae) near Tapachula, Chiapas, Mexico. Can. Entomol. 123, 353-359

Roubik, D.W. (1978) Competitive interactions between neotropical pollinators and Africanized honey bees. Science 201, 1030-1032

Roubik, D.W., Wolda, H. (2001) Do competing honey bees matter? Dynamics and abundance of native bees before and after honey bee invasion. Popul. Ecol. 43, 53-62

Roubik, D.W., Moreno, J.E., Vergara, C., Wittmann, D. (1986) Sporadic food competition with the African honeybee: projected impact on neotropical bees. J. Trop. Ecol. 2, 97-111

Rowell, G.A., Makela, M.E., Villa, J.D., Matis, J.H., Labougle, J.M., Taylor, O.R. (1992) Invasive dynamics of Africanized honeybees in North America. Naturwissenschaften 79, 281-283

Schneider, S.S., DeGrandi-Hoffman, G., Smith, D.R. (2004) The African honey bee: factors contributing to a successful biological invasion. Annu. Rev. Entomol. 49, 351-376

Shaibi, T., Lattorff, H.M.G., Moritz, R.F.A. (2008) A microsatellite DNA toolkit for studying population structure in Apis mellifera. Mol. Ecol. Resour. 8, 1034-1036

Walsh, P.S., Metzger, D.A., Higuchi, R. (1991) Chelex100 as a medium for simple extrctioon of DNA for PCR-based typing from forensic material. Biotechniques 10, 506-513

Wang, J. (2004) Sibship reconstruction from genetic data with typing errors. Genetics 166, 1963-1979

Williams, J.L. (1987) Wind-directed pheromone trap for drone honeybees (Hymenoptera: Apidae). J. Econ. Entomol. 80, 532-536

Woyke, J. (1963) What happens to the diploid drone larvae in a honeybee colony. J. Apic. Res. 2, 73-75

Zárate, O., De Araujo-Freitas, C., Medina, L.A., Velásquez, A., Quezada-Euán, J.J.G. (2008) Phenotypic correlations of field and laboratory tests with honey production in Africanized honey bees (Apis mellifera). Apidologie 39, 523-530

Zayed, A. (2004) Effective population size in Hymenoptera with complementary sex determination. Heredity 93, 627-630

Zayed, A. (2009) Bee genetics and conservation. Apidologie 40, 237-282 